\title{
Study on the Soil Corrosivity towards the Buried-Structures in Soil Environment of Tanglaphant-Tribhuvan University Campus-Balkhu
}

\section{Areas of Kirtipur}

\author{
M. Gautam and J. Bhattarai \\ Central Department of Chemistry, Tribhuvan University, Kathmandu \\ e-mail: bhattarai_05@yahoo.com
}

\begin{abstract}
Soil parameters such as moisture, $\mathrm{pH}$, resistivity, oxidation-reduction potential, chloride and sulfate ions were investigated, because these parameters affect the corrosive nature of soils toward the buried-galvanized steels and cast-iron pipelines used to supply drinking water in Tanglaphant-Tribhuvan University Campus-Balkhu areas of Kirtipur. The soil parameters examined in the study areas are found as: moisture (7-48\%), $\mathrm{pH}$ (7.0-7.9), resistivity (6,300-37,000 ohm.cm), oxidation-reduction potential (307-490 mV vs SHE), chloride (13-92 ppm) and sulfate (62-309 ppm) contents. The results gave an indication of mildly corrosive to non-corrosive nature of soils on the buriedgalvanized steels and cast-iron pipes used to supply drinking water in the study areas of Kirtipur.
\end{abstract}

Key words: soil corrosion, moisture content, resistivity, chloride and sulfate contents, oxidation-reduction potential.

\section{Introduction}

Corrosive environment is one of the key factors for the corrosion of engineering materials. The buriedmaterials like galvanized steels and cast-iron are important engineering materials which are widely used to supply drinking water, city gas and petroleum products. The study of the corrosion of these buriedstructural materials in soil is of major importance for underground soil corrosion, because millions of miles of the buried-materials are used to supply the drinking water, gas, oil and so on in the world. Corrosion of these buried-structural materials necessitates a huge amount of money for regular maintenance and replacement.

In general, the corrosivity of the buried-structural materials can be explained on the basis of two broad categories of soil environments, they are disturbed and undisturbed soils. The soil corrosivity towards the buried-structural materials in the undisturbed soil is generally negligible as compared with the corrosive nature of the disturbed soil (Uhlig \& Revie 1991, Bhattarai 2010 a, 2010 b). The corrosion rate of the buried-structural materials in the disturbed soil is influenced by numbers of soil parameters like moisture content, $\mathrm{pH}$, resistivity, oxidation-reduction potential, chloride, sulfate, sulfide and oxygen contents and so on (Uhlig \& Revie 1991, Bhattarai 2010 a, 2010 b). Numerous studies on soil corrosion of the buriedstructures have been carried out (Starkey \& Wight 1983, Benmoussa et al. 2006, Alamilla et al. 2009, Ismail \& El-Shamy 2009, Yahaya et al. 2011, Norhazilan 2012). Estimation of such soil parameters can give an indication of the soil corrosivity towards the buriedstructural materials like galvanized steel and cast-iron pipes. It has been reported that the corrosion of galvanized steels, bare steels and zinc after exposure to different soil conditions for a maximum of 13 years in early of 1950s (Denison \& Romanoff 1952). Similarly, the most comprehensive data available in the field of underground corrosion are the results of extensive field testing on the buried-metal pipes and steel sheets (Romanoff 1957). It has been reported that the corrosion of mild steel increased when soil moisture content exceeded $40 \%$ and suggested that the maximum corrosion rates occur at saturations of 6085\% (Denison \& Romanoff 1952). It has been reported that soil resistivity has the largest effect on the 
observed maximum average pitting corrosion rate on the surface of the buried-pipelines (Schashle \& Marsh 1963). Many buried-structural materials, such as galvanized water supply pipelines, natural gas and crude oil pipelines have been corroded by soils all around the world (Levlin 1992, Doyle 2000, Doyle et al. 2003, Rim-rukehand \& Awalefe 2006, Alhazzaa 2007, Shamsuri 2010). It has been reported that the aggressiveness of soil towards the drinking water supply pipeline used in Toronto city of Canada was affected by soil properties such as resistivity, $\mathrm{pH}$ and the presence of sulphate-reducing bacteria (Doyle et al. 2003). Study on Nigeria pipeline used to supply crude oil showed that the soil resistivity was found to be decreased with increasing the moisture content and temperature (Rim-rukehand \& Awalefe 2006).

Soils having high resistivity (i.e., low conductivity) are generally least corrosive for the buried-structural materials. It has been reported that the sandy and rocky soils have a high resistivity (more than 6000 ohm.cm) and therefore, considered to be mildly corrosive or excellent corrosion resistance for the galvanized steels and cast-iron pipes, while a clayey soil with a resistivity less than 1000 ohm.cm is generally considered to be highly corrosive for the buried-galvanized steels (Uhlig \& Revie 1991, Bhattarai 2010 a, 2010 b). The effect of chloride concentration in soil on the corrosion behavior of reinforcing steels was studied (Maslehuddin et al. 2007). Compared to the corrosive effect of chloride $\left(\mathrm{Cl}^{-}\right)$ion, sulfate is generally considered to be more benign in their corrosive action towards the buried-metallic substances. However, the presence of sulfate amounts more than $200 \mathrm{ppm}$ in soils can pose a major risk for the structural materials (Robinson 1993, Escalante 1989, Bayliss \& Deacon 2002), because it can readily be converted to highly corrosive sulfides by anaerobic sulfate-reducing bacteria. It has been reported that soil is generally considered mildly corrosive if the sulfate and chloride ions are below 200 ppm and 100 ppm, respectively, for soils with $\mathrm{pH}$ of 5-9 and the resistivity greater than 5,000 ohm.cm (Uhlig \& Revie 1991, Bhattarai 2010 a, 2010 b, Robinson 1993, Escalante 1989).

The city supply water from reservoirs to distribution terminal is mostly through the buried-galvanized steels and cast-iron pipelines in Nepal. The galvanized steels and cast-iron pipes, although susceptible to corrosion are widely used in Nepal, because of their low cost and high strength. In this context, it is very urgent to investigate the effects of different soil parameters that affect the corrosive nature of soils on the buriedgalvanized steel pipelines used to supply city water in Kathmandu Valley. The main objectives of this study are to know the effect of soil parameters on the corrosivity of the buried-structural materials like galvanized steels and cast-iron pipelines and to specify the corrosive nature of soil of Tanglaphant-Tribhuvan university campus-Balkhu areas of Kirtipur.

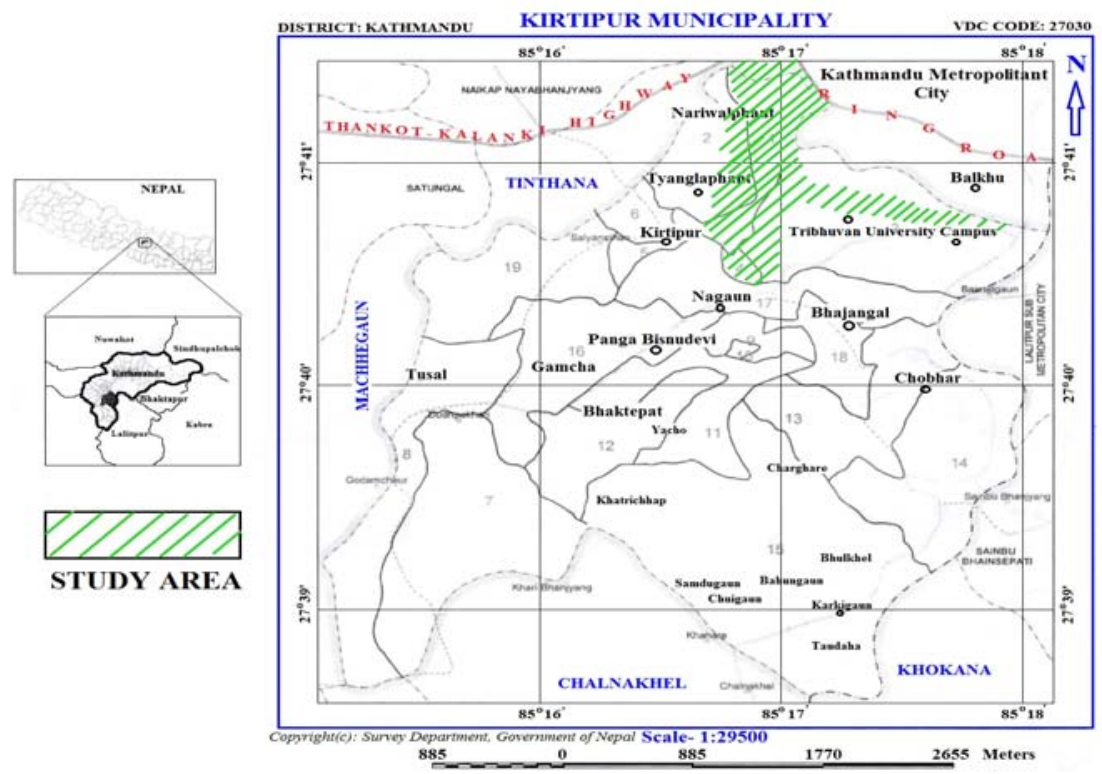

Fig.1. Location map of the sampling site of Tanglaphant-Tribhuvan University Campus-Balkhu areas of Kirtipur 
M. Gautam \& J. Bhattarai/Study on the Soil Corrosivity towards ....

\section{Methodology}

Thirty soil samples were collected from the Tanglaphant-Tribhuvan university campus-Balkhu area of Kirtipur which is located within the latitude of $27^{\circ} 40^{\prime} 56^{\prime \prime}-27^{\circ} 41^{\prime} 30^{\prime \prime} \mathrm{N}$ and within the longitude of $85^{\circ} 16^{\prime} 45^{\prime \prime}-85^{\circ} 18^{\prime} 05^{\prime \prime} \mathrm{E}$. The sampling area is in the north-eastern part of Kirtipur municipality as shown in Fig. 1. All the soil samples were taken from the depth of about $1 \mathrm{~m}$ from the ground level for the real location of the buried-pipelines for the purpose of the supply of drinking water in the months of July 2011 to March 2012. Among thirty soil samples, eleven samples (i.e., TUCB1-TUCB11) were collected from the side of the Nayabazar-Tangla-Sita petrol pump road (Tanglaphanta), ten samples (i.e., TUCB12-TUCB21) were collected from TU main gate to M Phil building (Tribhuvan university campus), while remaining nine samples were collected from Sita petrol pump to Kalanki crossing (Balkhu). The distance between two samples was generally 300 to $500 \mathrm{~m}$ the apart. The soil samples were taken in air tight polyvinyl bags so that moisture remained same for a period of moisture content analysis in the laboratory.

Moisture content in soil was determined using weight loss method in accordance with the ASTM D4959-07 standards (ASTM D4959-07 2007). A digital pH meter was used to determine the $\mathrm{pH}$ of 1:2 soil-water suspension of each soil sample in accordance with the ASTM G51-95 (2012) standards (ASTM G51-95 2012). The conductivity bridge was used to determine the electrical conductivity of the 1:2 soil-water suspension in accordance with the ASTM G187-05 standards (ASTM G187-05 2005). The soil resistivity (bulk/saturated paste) was calculated from the conductivity. The oxidation-reduction potential (ORP) of the soil samples was measured with the help of a digital potentiometer in accordance with the ASTM G200-09 standards (ASTM G200-09 2009). The platinum wire and saturated calomel electrodes (SHE) were used as working and reference electrode, respectively. The recorded ORP values vs SCE was converted to reference value of the saturated hydrogen electrode (SHE). Argentometric titration was used to determine the amount of chloride content in soil. Chloride content in the 1:2 soil-water suspension was determined by titrating the soil suspension against standard silver nitrate solution using potassium chromate as an indicator. Gravimetric method was used to estimate the amounts of sulfate content in soil samples. The details of these all methods are discussed elsewhere (Gautam 2012, Bhattarai 2013a, 2013b, 2013c, Bhandari et al. $2013 \mathrm{c}$ ).

\section{Results and Discussion}

Soil corrosivity is not a directly measurable parameter and the corrosion of the buried-structural materials is largely a random phenomena. This research work is replete with methods and systems that attempt to predict soil corrosivity and resulting the underground structural materials corrosion from different soil parameters of Tanglaphant-Tribhuvan University Campus-Balkhu areas of Kiritpur.

\section{Moisture content in soil}

The moisture content in the collected soil samples ranged from $7-48 \%$. Among thirty soil samples, two soil samples contained less then $10 \%$, while twelve samples contained $10-20 \%$, fourteen samples contained $21-40 \%$ and only two samples contained more than $40 \%$ moisture content as shown in Table 1.

These results revealed that the soil samples holding less than $40 \%$ moisture content are probably due to the mixture of sand and clay or sandy soils. These results revealed that most of the soil samples are assumed to be mildly corrosive to non-corrosive towards the buried-galvanized steels and cast-iron pipelines on the basis of the soil moisture content (Table 1). It is meaningful to mention here that soil moisture content greatly affects on the soil resistivity. In general, high amounts of soil moisture content enhanced to increase the electrical conductivity or decrease the soil resistivity. Dry soil shows very high resistivity than that of wet soil and hence dry soil is assumed to be less corrosive than wet soils.

\section{Soil pH}

All thirty soil samples collected from the TanglaphantTribhuvan University Campus-Balkhu areas of Kiritpur are neutral or slightly alkaline in nature showing the $\mathrm{pH}$ values in the range of 7.0-7.9 as shown in Table 1. Among these soil samples, ten samples were neutral and remaining twenty samples wee slightly alkaline in nature. The results revealed that all thirty soil samples analyzed in this research work are assumed to be mildly corrosive to non-corrosive nature towards the galvanized steels and cast-iron pipelines based on the observed soil $\mathrm{pH}$ values. However, $\mathrm{pH}$ value is not the 
only parameter that affects the soil corrosivity towards the buried-galvanized steels and cast-iron pipelines.

\section{Soil resistivity}

The soil resistivity is actual bulk resistivity of soil influences by types of soil, moisture content, concentration of different dissolved salts, degree of compactness and temperature so on. Since the soil resistivity was not measured in the sampling sites, all these affecting factors except types, moisture content and dissolved salts are changed from their in-situ values. Hence, in this research work, all efforts were made to insure uniformity among the resistivity tests performed in the laboratory. All soil samples were tested at room temperature at $25^{\circ} \mathrm{C}$ which was remained constant and an effort was made to compact the soils to the same degree into the square soil box.

Table 1. Corrosive parameters of soils collected from Tanglaphant-Tribhuvan University Campus-Balkhu areas of Kirtipur Municipality

\begin{tabular}{|c|c|c|c|c|c|c|c|}
\hline S.N. & Samples Name & $\begin{array}{c}\text { Moisture Content } \\
\text { (\%) }\end{array}$ & Soil pH & $\begin{array}{l}\text { Soil Resistivity } \\
\text { (ohm.cm) }\end{array}$ & $\begin{array}{c}\text { ORP } \\
\text { (mV vs SHE) }\end{array}$ & $\begin{array}{l}\text { Chloride } \\
\text { (ppm) }\end{array}$ & $\begin{array}{l}\text { Sulphate } \\
\text { (ppm) }\end{array}$ \\
\hline 1 & TUCB1 & 20 & 7.6 & 20,800 & 383 & 35 & 110 \\
\hline 2 & TUCB2 & 17 & 7.7 & 17,900 & 385 & 33 & 110 \\
\hline 3 & TUCB3 & 15 & 7.8 & 18,500 & 441 & 47 & 82 \\
\hline 4 & TUCB4 & 19 & 7.6 & 23,800 & 307 & 68 & 67 \\
\hline 5 & TUCB5 & 18 & 7.5 & 26,300 & 395 & 38 & 82 \\
\hline 6 & TUCB6 & 16 & 7.9 & 20,800 & 418 & 42 & 102 \\
\hline 7 & TUCB7 & 30 & 7.2 & 10,200 & 342 & 55 & 192 \\
\hline 8 & TUCB8 & 32 & 7.2 & 10,400 & 361 & 52 & 165 \\
\hline 9 & TUCB9 & 24 & 7.1 & 13,200 & 344 & 64 & 137 \\
\hline 10 & TUCB10 & 30 & 7.1 & 10,000 & 331 & 67 & 137 \\
\hline 11 & TUCB11 & 44 & 7.0 & 6,330 & 353 & 58 & 110 \\
\hline 12 & TUCB12 & 35 & 7.3 & 7,250 & 388 & 63 & 165 \\
\hline 13 & TUCB13 & 48 & 7.1 & 8,060 & 362 & 75 & 137 \\
\hline 14 & TUCB14 & 24 & 7.4 & 7,940 & 385 & 51 & 219 \\
\hline 15 & TUCB15 & 34 & 7.3 & 7,460 & 366 & 68 & 165 \\
\hline 16 & TUCB16 & 34 & 7.6 & 6,670 & 372 & 85 & 192 \\
\hline 17 & TUCB17 & 20 & 7.6 & 10,000 & 375 & 82 & 247 \\
\hline 18 & TUCB18 & 24 & 7.5 & 7,580 & 381 & 51 & 137 \\
\hline 19 & TUCB19 & 24 & 7.7 & 6,940 & 425 & 58 & 282 \\
\hline 20 & TUCB20 & 28 & 7.8 & 8,770 & 440 & 42 & 302 \\
\hline 21 & TUCB21 & 31 & 7.7 & 8,470 & 337 & 75 & 274 \\
\hline 22 & TUCB22 & 17 & 7.6 & 20,800 & 437 & 49 & 82 \\
\hline 23 & TUCB23 & 7 & 7.6 & 37,000 & 445 & 13 & 70 \\
\hline 24 & TUCB24 & 7 & 7.7 & 35,700 & 420 & 17 & 62 \\
\hline 25 & TUCB25 & 26 & 7.6 & 9,170 & 446 & 92 & 225 \\
\hline 26 & TUCB26 & 13 & 7.8 & 23,800 & 442 & 45 & 147 \\
\hline 27 & TUCB27 & 22 & 7.4 & 20,400 & 407 & 50 & 165 \\
\hline 28 & TUCB28 & 11 & 7.8 & 22,700 & 418 & 67 & 77 \\
\hline 29 & TUCB29 & 16 & 7.9 & 22,200 & 490 & 64 & 89 \\
\hline 30 & TUCB30 & 13 & 7.7 & 25,600 & 489 & 38 & 165 \\
\hline
\end{tabular}

Table 1 shows the soil resistivity of soil samples collected from Tanglaphant-Tribhuvan university campus-Balkhu areas of Kiritpur. The resistivity of all thirty soils ranges from 6,300 to 37,000 ohm.cm. Among these soil samples, thirteen samples had the soil resistivity between 5,000 and 10,000 ohm.cm, five samples had between 10,000 and 20,000 ohm.cm and twelve samples had higher than 20,000 ohm.cm as shown in Table 1.
These results revealed that most of the soil samples collected from the study areas is mildly corrosive to essentially non-corrosive in nature for the buriedstructural materials according to the ASTM (Escalante 1989) and NACE (NACE 1993) classifications based on the bulk soil resistivity values. It is meaningful to mention here that the soil corrosivity towards the buried-structural materials was classified into six groups (that is, essentially non-corrosive, mildly 
M. Gautam \& J. Bhattarai/Study on the Soil Corrosivity towards ......

corrosive, moderately corrosive, corrosive, highly corrosive and extremely corrosive) as shown in Table 2 (Robinson 1993, Escalante 1989, NACE 1993).

\section{Oxidation-reduction potential of soil}

The measurement of the oxidation-reduction potential (ORP) of soils is significant to explain the soil corrosivity towards the buried-structural materials, because it determines partially the stability of the materials. In general, an anaerobic soils having low ORP less than about $100 \mathrm{mV}$ vs SHE are not helpful for formation of rust/oxide layer on the surface of the materials (Jones 1996). The ORP value of all thirty soil samples collected from the Tanglaphant-Tribhuvan university campus-Balkhu areas of Kiritpur is in the range of 307-490 $\mathrm{mV}$ vs SHE as shown in Table 1. Among these soil samples, seventeen samples had ORP values in the ranges of $300-400 \mathrm{mV}$ vs SHE and other remaining thirteen samples had more than 400 $\mathrm{mV}$ vs SHE ORP. These results revealed that all soil samples collected from the Tanglaphant-Tribhuvan university campus-Balkhu areas of Kiritpur are belonged to mildly corrosive to non-corrosive for the buried-structural materials based on the Johes' classification (also given in Table 3) (Jones 1996).

\section{Chloride content in soil}

The contribution of chloride ions to soil corrosivity towards the buried-materials is very significant. The chloride ions also participate directly in pit initiation on the surface of stainless steels. They are not only promoting the pitting corrosion of stainless steels, but also inhibit the passivity of the buried-structural materials (Uhlig \& Revie 1991). The chloride content in all thirty soil samples collected from the Tanglaphant-Tribhuvan university campus-Balkhu areas of Kiritpur is found to be in the range of 13-92 ppm as shown in Table 1. Among these soil samples, ten samples had less than $50 \mathrm{ppm}$, while remaining twenty samples had between 50-100 ppm chloride content as presented in Table 1 . These results revealed that soils of the Tanglaphant-Tribhuvan university campus-Balkhu areas of Kiritpur are considered to be mildly corrosive to non-corrosive towards the galvanized and cast-iron pipelines used to supply the drinking water in the areas, because the soils containing less than $100 \mathrm{ppm}$ chloride content and more than 5000 ohm.cm soils resistivity are categorized as the mildly corrosive to non-corrosive soils towards the buried-structural materials (Robinson 1993, Escalante 1989, NACE 1993).

\section{Sulfate content in soil}

Sulfate content in soil is generally harmful for the buried-structural materials, because it participates directly in pit initiation of stainless steels and also increases the soil conductivity. It is reported that soils containing less than 200 ppm of sulfate is considered as “mildly corrosive” (Robinson 1993, Escalante 1989, NACE 1993). Table 1 shows sulfate content in all thirty soil samples which is found less than $200 \mathrm{ppm}$. Among these soil samples, seven soils contained between 50100 ppm sulfate, ten samples contained between 101150 ppm, six samples contain 151-200 ppm, while remaining seven soil samples contained more than 200 ppm sulfate. These results revealed that all soil samples of the Tanglaphant-Tribhuvan university campusBalkhu areas of Kiritpur are considered to be mildly corrosive to non-corrosive towards the galvanized steels and cast-iron pipelines.

In summary, Most of soils of the TanglaphantTribhuvan university campus-Balkhu areas of Kiritpur are sandy or mixture of sand and clay which are assumed to be mildly corrosive to non-corrosive in nature towards the buried-galvanized steels and castiron pipes. The soil $\mathrm{pH}$ value is found to be within the limits of 7.0-7.9 pH for showing mildly corrosive to noncorrosive towards the buried-galvanized steels and cast-iron pipelines.

A very high soil resistivity (i.e., > 5000 ohm.cm) of all thirty soil samples supports the moderately corrosive to essentially non-corrosive nature of soils of the Tanglaphant-Tribhuvan university campus-Balkhu areas of Kiritpur. All soil samples have the oxidationreduction potential values above $300 \mathrm{mV}$ vs SHE, which shows the mildly corrosive to non-corrosive nature of soil towards the buried-galvanized steels and cast-iron pipelines.

All examined soil samples contained less than $100 \mathrm{ppm}$ chloride, less than 200 ppm sulfate and more than 5,000 ohm.cm soil resistivity and hence showed mildly corrosive to essentially non-corrosive nature towards the buried-galvanized steels and cast-iron pipelines used to supply the drinking water in the TanglaphantTribhuvan university campus-Balkhu areas of Kiritpur. 
Table 2. Relationship between soil resistivity, chloride and sulphate content and soil corrosivity towards the buried-structural materials (Robinson 1993, Escalante 1989, NACE 1993).

\begin{tabular}{c|l}
\hline \multicolumn{1}{c|}{ Soil Parameter } & \multicolumn{1}{|c}{ Soil Corrosivity Rate } \\
\hline 1.Soil Resistivity (ohm.cm) & \\
$>20,000$ & Essentially non-corrosive \\
$10,000-20,000$ & Mildly corrosive \\
$5,000-10,000$ & Moderately corrosive \\
$3,000-5,000$ & Corrosive \\
$1,000-3,000$ & Highly corrosive \\
$<1,000$ & Extremely corrosive \\
2.Chloride Content (ppm) & Mildly corrosive \\
$<100$ & \\
3.Sulfate Content (ppm) & Mildly corrosive \\
$<200$ &
\end{tabular}

Table 3. Rating of soil corrosivity based on the oxidation-reduction potential of soils (Jones 1996).

\begin{tabular}{c|l}
\hline $\begin{array}{c}\text { Oxidation-reduction } \\
\text { Potential (mV vs SHE) }\end{array}$ & \multicolumn{1}{|c}{ Soil Corrosivity } \\
\hline$>400$ & Non-corrosive \\
$201-400$ & Mildly corrosive \\
$100-200$ & Moderately corrosive \\
$<100$ & Severe corrosive \\
\hline
\end{tabular}

\section{Acknowledgements}

Authors would like to acknowledge to Nepal Academy of Science and Technology (NAST) for providing the NAST research grant-2067 (Grant No.:536-067/068) to one of the present authors (JB) for supporting to conduct this research work at the Central Department of Chemistry, Tribhuvan University, Kathmandu. Also we express our sincere thanks to Head of Central Department of Chemistry, Tribhuvan University for providing the available research facilities to conduct this research work in the department.

\section{References}

Alamilla, J. L., M. A. Espinosa-Medina and E. Sosa. 2009. Modelling steel corrosion damage in soil environment. Corrosion Science 51:2628-2638.

Alhazzaa, M. I. 2007. A comparative study of soil corrosivity of the university campus. Final Research Report No. 45/426, King Saud University College of Engineering Research Center, 27 pp.

ASTM G187-05. 2005. Standard test method for measurement of soil resistivity using two-electrode soil box method. Annual Book of ASTM Standards, American Society for Testing and Materials.

ASTM D4959-07. 2007. Standard test method for determination of water (moisture) content of soil by direct heating. Annual Book of ASTM Standards, American Society for Testing and Materials.

ASTM G200-09. 2009. Standard test method for measurement of oxidation-reduction potential (ORP) of soil. Annual Book of ASTM Standards, American Society for Testing and Materials.

ASTM G51-95(2021). 2012. Standard test method for measurement of $\mathrm{pH}$ of soil for use in corrosion testing. Annual Book of ASTM Standards, American Society for Testing and Materials.

Bayliss, D. A. and H. Deacon. 2002. Steelwork corrosion control, $2^{\text {nd }}$ edition, Spon Press, London.

Benmoussa, A., M. Hadjel and M. Trainel. 2006. Corrosion behaviour of low carbon pipeline steel in soil environment. Materials and Corrosion 57(10):771-777.

Bhattarai, J. 2010 a. Frontiers of corrosion science. $1^{\text {st }}$ edition, Kshitiz Publ., Kirtipur, Kathmandu. Nepal. 304pp.

Bhattarai, J. 2010 b. Spectrum. An Annual Science Magazine of ChemSA, Central Department of Chemistry, Tribhuvan University, Kirtipur 15:9-14.

Bhattarai. J. 2013 a. Investigation of soil parameters for their corrosivity on buried-galvanized steel pipelines used in Kathmandu valley, Research report, submitted to Nepal Academy of Science and Technology, Khumaltar, Lalitpur, Nepal, 41pp.

Bhattarai. J. 2013 b. Study on the corrosive nature of soil towards the buried-structures. Scientific World 11(11):43-47.

Bhandari, P. P., Dahal, K. P. and Bhattarai. J. 2013 c. The corrosivity of soils collected from Araniko Highway and Sanothimi areas of Bhaktapur, Nepal. Journal of Institute of Science and Technology 18(1):71-77

Denison, I. A. and M. Romanoff. 1952. Corrosion of galvanized steel in soils. Journal of Research of the National Bureau of Standards 49(5):299-316.

Doyle, G. 2000. The role of soil in the external corrosion of cast iron water mains in Toronto, Canada. MS thesis, Graduate Department of Civil Engineering, University of Toronto, Canada, 75pp.

Doyle, G., M. V. Seica and M. W. F. Grabinsky. 2003. The role of soil in the external corrosion of cast iron water mains in Toronto. Canadian Geotechnological Journal 40(2):225-236.

Escalante, E. 1989. Effects of soil characteristics on corrosion, in Concepts of Underground Corrosion (eds V. Chaker and J. D. Palmer), American Society for Testing and Materials, Philadelphia.

Gautam, M. 2012. Investigation on different soil parameters of Tanglaphant-Tribhuvan University Campus-Balkhu 
M. Gautam \& J. Bhattarai/Study on the Soil Corrosivity towards ......

areas of Kirtipur for their corrosive nature. M.Sc. Dissertation, Central Department of Chemistry, Tribhuvan University, Kathmandu, Nepal.

Ismail, A. I. and A. M. El-Shamy. 2009. Engineering behaviours of soil materials on the corrosion of mild steel. Applied Clay Science 42:356-362.

Jones, D. A. 1996. in Principles and prevention of corrosion. $2^{\text {nd }}$ edition, Prentice Hall.

Levlin, E. 1992. Corrosion of water pipe systems due to acidification of soil and groundwater. Department of Applied Electrochemistry and Corrosion Science, Royal Institute of Technology, Stockholm.

Maslehuddin, M., M. M. Al-Zahrani, M. Ibrahim, M. H. Al-Methel and S. H. Al-Idi. 2007. Journal of Construction and Building Material 21:1825-1832.

NACE. 1993. Underground corrosion. National Association of Corrosion Engineering (NACE) Publications, the Corrosion/93 Symposium.

Norhazilan,M. N., Y. Nordin, K. S. Lim, R. O. Siti, A. R. A. Safuan and M. H. Norhamimi. 2012. Relationship between soil properties and corrosion of carbon steel. Journal of Applied Science Research 8(3):1739-1747.

Rim-rukehand, A. and J. K. Awalefe. 2006. Investigation of soil corrosivity in the corrosion of low carbon steel pipe in soil environment. Journal of Applied Science Research 2(8):466-469.

Robinson, W. 1993. Testing soil for corrosiveness. Materials Performance 32(4):56-58.

Romanoff, M. 1957. Underground Corrosion. Circ. 579, US National Bureau of Standards.

Schashle, E. and G. A. Marsh. 1963. Some new views on soil corrosion. Materials Protection 2:8-17.

Shamsuri, S. R. B. 2010. The effect of soil resistivity on corrosion behavior of coated and uncoated low carbon steel. ME thesis, Faculty of Mechanical Engineering, University Teknologi Malaysia, Malaysia.

Starkey, R. L. and K. M. Wight. 1983. Anaerobic corrosion of iron in soil. American Gas Association Bulletin 17:11-13.

Uhlig, H. H. and R. W. Revie. 1991. in Corrosion and corrosion control; In: an introduction to corrosion science and engineering, $3^{\text {rd }}$ edition, John Wiley and Sons, NewYork, 441pp.

Yahaya, N., K. S. Lim, N. M. Noor, S. R. Othmman and A. Abdulla. 2011. Effect of clay and moisture content on soil-corrosion dynamic. Malaysian Journal of Civil Engineering 23(1):24-32. 
Nepal Journal of Science and Technology Vol. 14, No.2 (2013) 65-72 